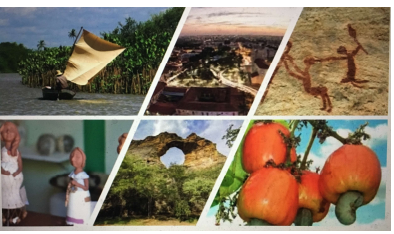

ISBN: 2675-1496 DOI: https://doi.org/10.26694/caedu.v1i2.9831

\title{
ORANGE IS THE NEW BLACK E O SILÊNCIO SOBRE O ENCARCERAMENTO DE MULHERES
}

Ana Maria Marques

Docente do Programa de Pós-graduação em História

Universidade Federal de Mato Grosso

ORCID: https://orcid.org/0000-0002-4853-8200

Fernanda Nogueira da Cruz

Graduanda Pedagogia

Universidade Federal de Mato Grosso

Resumo: Inspirado na obra literária Orange is the new black que originou a série homônima, esse texto faz um paralelo entre tramas que envolvem mulheres encarceradas no Brasil e nos Estados Unidos. Temas como drogas, maternidade, racismo, exploração do trabalho são tratados em diálogo com algumas autoras feministas.

Palavras-chave: Orange is the new black, mulheres encarceradas, autoras feministas

Abstract: Inspired by the literary work Orange is the new black that originated the eponymous series, this text try to do a conection between incarcerated women in Brazil and the United States. Topics such as drugs, motherhood, racism, labor exploitation are discussed in dialogue with some feminist authors.

Keyworks: Orange is the new black, incarcerated women, feminist authors.

Resumen: Inspirado en la obra literaria, Orange is the new black, que originó la serie homónima, este texto es paralelo a tramas que involucran a mujeres encarceladas en Brasil y Estados Unidos. Temas como drogas, maternidad, racismo, explotación laboral se discuten en diálogo con algunas autoras feministas.

Palabras clave: Orange is the new black, mujeres encarcelada, autoras feministas.

Este trabalho foi produzido em coautoria. Nos últimos três anos, Ana Maria Marques, professora doutora em História, tem amadurecido o trabalho educacional junto a uma penitenciária feminina em Mato Grosso. A experiência iniciou levando estudantes de graduação a fazer estágio na escola da unidade prisional de Educação de Jovens e Adultos (EJA), depois migrou para um voluntariado com o objetivo de tirar do papel o projeto de remição pela leitura da Secretaria de Justiça e Direitos Humanos (SEJUDH). Atualmente essa parceria segue paralela à pesquisa sobre experiências educativas em Revista Caminhos da Educação: diálogos, culturas e diversidades. CAEDU/UFPI 


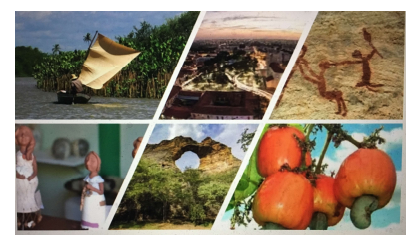

ISBN: 2675-1496 DOI: https://doi.org/10.26694/caedu.v1i2.9831

unidades prisionais femininas. Fernanda Nogueira da Cruz esteve a cumprir pena em regime fechado na mesma penitenciária citada. Em 2015, trabalhou como assistente da coordenadora pedagógica da unidade prisional, que sempre a incentivou a ler e estudar. Em 2016, fez o ENEM (Exame Nacional do Ensino Médio) e obteve pontuação suficiente para ingressar em uma universidade, mas não foi possível sair para estudar uma vez que não existia escoltas disponíveis para levá-la às aulas. Em 2017, fez o exame pela segunda vez e conseguiu uma vaga e uma oportunidade de estudar na Universidade Federal de Mato Grosso (UFMT). Em 2019, retornou à penitenciária por seis meses e participou do projeto de remição pela leitura, que sonhava já ter podido fazer quando esteve por lá em anos anteriores, mas não havia. Atualmente, cumpre pena em regime semiaberto e cursa Pedagogia na UFMT. As experiências de ambas, embora sob diferentes pontos de vista, foram fundamentais para definirem os lugares de fala e justificar o interesse sobre o tema do encarceramento, sobretudo de mulheres.

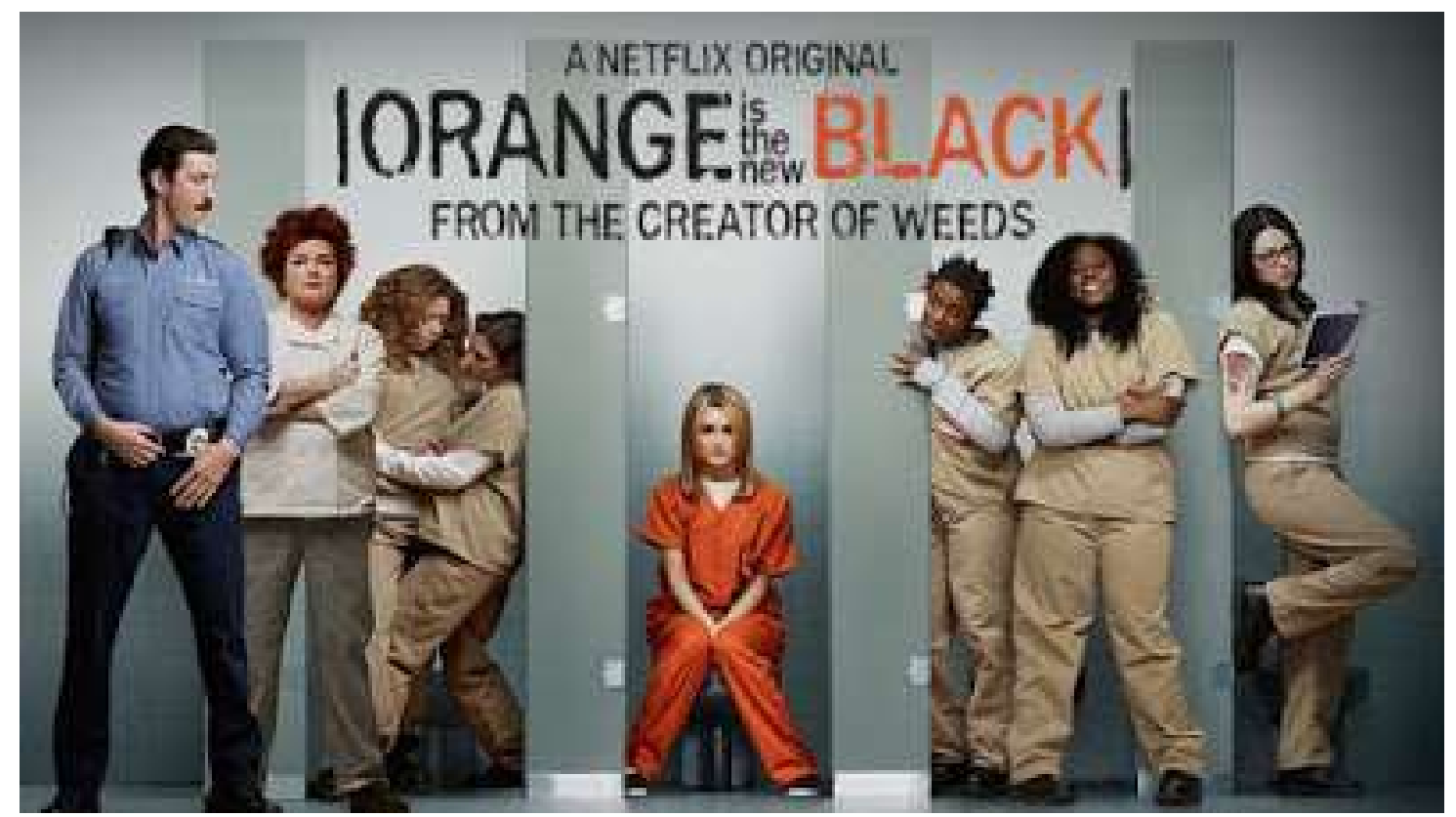

Figura 1 - Reprodução da capa do livro homônimo publicado no Brasil pela Editora Intrínseca, em 2014.

Orange is the new black - livro e série nos tocaram e sensibilizaram sobremaneira.

Embora se trate de contextos e realidades diferentes, Brasil e Estados Unidos (EUA), Revista Caminhos da Educação: diálogos, culturas e diversidades. CAEDU/UFPI 


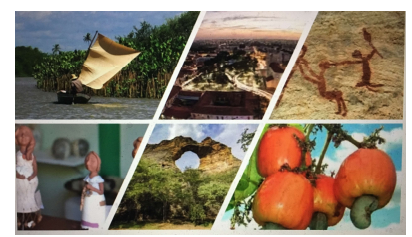

ISBN: 2675-1496 DOI: https://doi.org/10.26694/caedu.v1i2.9831

percebemos cruzamentos e aproximações de situações muito semelhantes às que se passam em prisões dos dois países. A dimensão educativa da série é, antes de tudo, de nos confrontar com a vida que corre à margem do mundo fora das prisões e do quão difícil é atravessar esses processos condenatórios que, por vezes, atacam a dignidade humana, mas por outras, constroem redes de solidariedade, resistências e possibilidades de viver e aprender.

Durante suas sete temporadas, Orange is the new black se manteve com índices impressionantes de audiência nos EUA. No Brasil, a empresa estadunidense Netflix exibiu a série via streaming e confirmou o sucesso de público. A capa do livro, como se vê na Figura 1 desse texto destaca parte do elenco e centraliza Taylor Schilling (Figura 2), que interpretou a autora e protagonista da história, Piper Kerman (Piper Chapman, na série). O livro foi publicado nos EUA em 2010 e a série estreou lá em julho de 2013. Então, quando o livro foi traduzido para o português por Claudio Figueiredo e Lurdes Sette e publicado no Brasil em 2014, a série já fazia sucesso nos EUA.

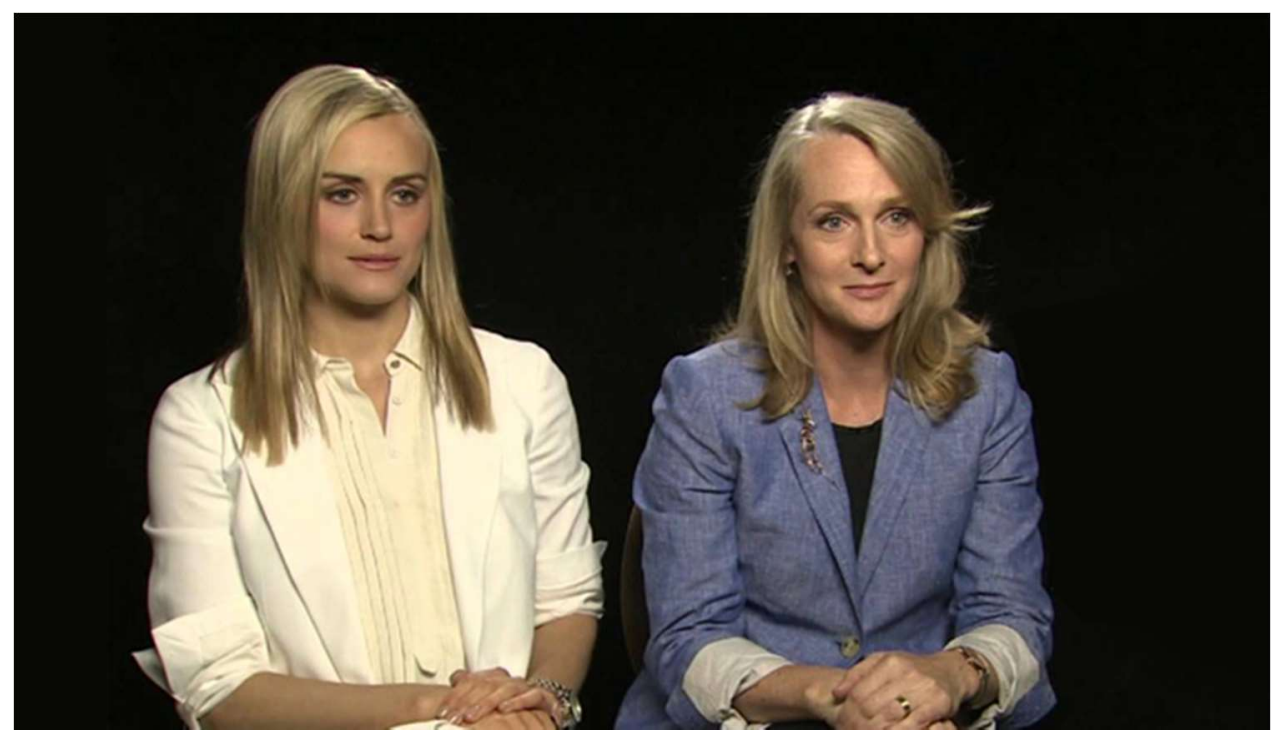

Figura 2 - Intérprete e protagonista da vida real: Tylor Schilling e Piper Kerman.

O livro Orange is the new black é uma obra autobiográfica de Piper Kerman. Em 18 capítulos, a autora relatou o drama de glória e queda, da vida de luxo e luxúria, à condenação, dez anos depois, a quinze meses de reclusão no Instituto Correcional Federal Revista Caminhos da Educação: diálogos, culturas e diversidades. CAEDU/UFPI

Teresina, Brasil, v. 1, n. 2, p. 21-38, maio/agosto de 2019. ISBN: 2675-1496

DOI: https://doi.org/10.26694/caedu.v1i2.9831 


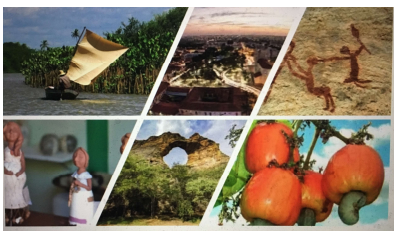

ISBN: 2675-1496 DOI: https://doi.org/10.26694/caedu.v1i2.9831

de Danbury, em Connecticut (EUA), por participação em um esquema internacional de tráfico de drogas e lavagem de dinheiro, durante uma passagem pela Europa. A sentença que a levou a cumprir pena em regime fechado foi proferida em dezembro de 2003. Nesse ínterim, Piper voltou para os EUA e levava uma vida normal. Antes de ser presa trabalhava numa empresa de infomerciais de TV. Conheceu Larry, um rapaz tímido de família judia, que dirigia uma agência de notícias. Na série ele parece mais palerma que no livro, mas também de menor estatura que na série. Piper e Larry se tornaram melhores amigos porque ele a considerava sua melhor consultora lésbica, então, sentia-se à vontade para pedir conselhos sobre mulheres. Mas à medida que eles se tornavam mais próximos e confidentes foi surgindo uma paixão. Piper decidiu acompanhar Larry quando ele recebeu uma proposta para se tornar editor-chefe numa revista masculina. Ela seguiu como freelancer. Durante todo o tempo da pena, Larry se manteve fiel e leal à Piper, ao contrário do que se desenvolve na série. O livro é narrado em primeira pessoa, focado muito mais no cotidiano e nos desafios da pena que nas histórias particulares de personagens que vão se destacando ao longo da série.

Na narrativa do livro e da série nos deparamos com uma Piper que não é mais a jovem inconsequente do passado. Ela não é a mesma passados dez anos da prática ilícita: tinha emprego, residência fixa, relacionamento estável e o sistema carcerário não lhe serviria como correção - porque ela já havia mudado. No entanto, foi levada a cumprir uma pena de quinze meses em regime fechado, exposta a outras possibilidades de crimes. Ela poderia cumprir sentença em prisão domiciliar ou pagar com pena alternativa de prestação de serviços comunitários em um órgão estadual e ainda devolveria à sociedade algo produtivo e relevante. Mas, não! O sistema é punitivo. Ao chegar na prisão, ela é orientada a não arrumar problemas e é encaminhada para sua cela, onde conhece suas companheiras de "dormitório" (termo que Piper utiliza no livro). Apesar da orientação, Piper se mete em confusão logo nos primeiros dias ao criticar a refeição servida e acaba ofendendo a cozinheira (apelidadas de Pop ou Red) que declara guerra contra ela - muito embora mais tarde viessem a se tornar amigas. 


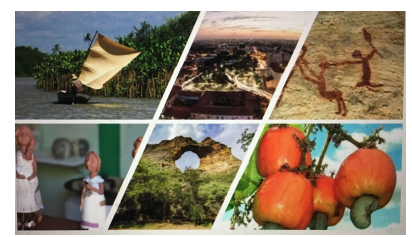

ISBN: 2675-1496 DOI: https://doi.org/10.26694/caedu.v1i2.9831

A série traz várias personagens carismáticas, além da protagonista. "Olhos loucos", ou Suzanne, interpretada por Uzo Aduba (Figura 3), atriz estadunidense de ascendência nigeriana, é uma das personagens que se mantém na série do início ao fim. Sua atuação em Orange lhe rendeu nos EUA várias indicações e prêmios de atriz coadjuvante, entre eles dois Emmy, um em 2014 e outro em 2015.

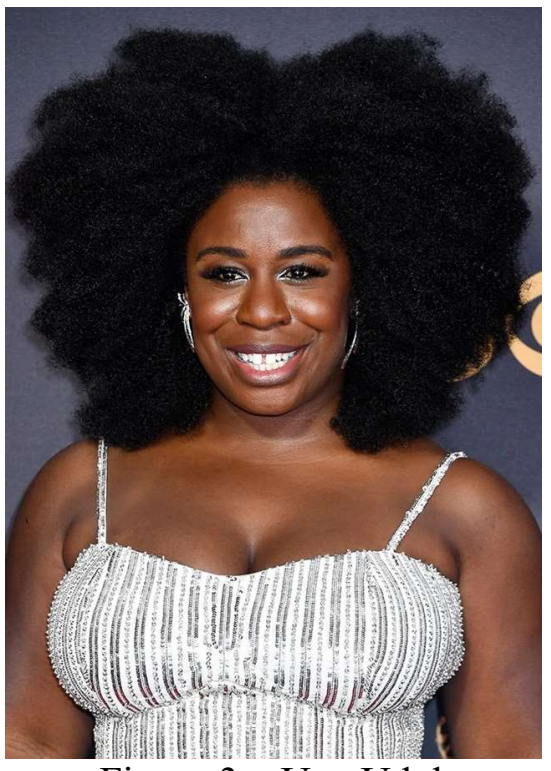

Figura 3 - Uzo Uduba.

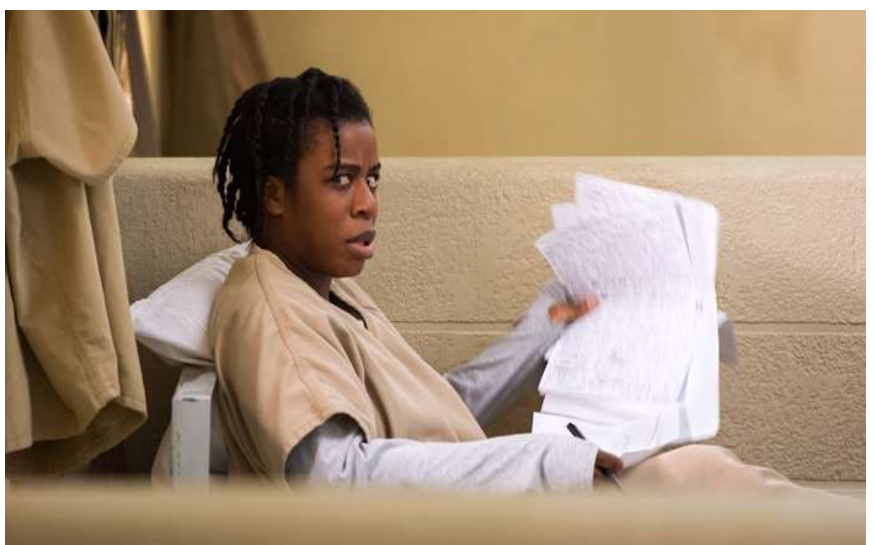

Figura 4 - Uzo Uduba interpretando Suzanne.

A Suzanne da série foi presa por ser considerada um risco à sociedade, pois foi acusada de homicídio de um menino, parecia ter algum distúrbio mental, mas também se revela cheia de talentos e inteligência. Na Figura 4 ela está em meio a muitos papéis, pois na quinta temporada se tornou também autora de obras de ficção e conquistou as leitoras da unidade prisional com fantasiosas histórias eróticas e personagens mirabolantes.

A série destaca mais as personagens negras que no livro - o que corrobora a lógica racial do encarceramento. Como diz Angela Davis (2018, p. 16): "Devido ao poder persistente do racismo, 'criminosos' e 'malfeitores' são, no imaginário coletivo, idealizados como pessoas de cor". Davis (2018, p. 20-21) acrescenta que, nos EUA, um estudo de 1995 apontou que a cada três homens encarcerados, um é negro, e a cada dez um é latino; ainda ela conta que a população feminina encarcerada, em cinco anos (de 


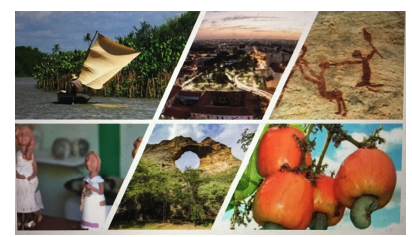

ISBN: 2675-1496 DOI: https://doi.org/10.26694/caedu.v1i2.9831

1990 a 1995) aumentou em 78\%. Como nos EUA, no Brasil, a população carcerária feminina representa cerca de 5\% do encarceramento total. Juliana Borges (2018, p.85) informa que " $67 \%$ da população prisional no Brasil é negra (tanto dentre homens quanto dentre mulheres)".

A personagem negra Tasha Jefferson ou Taystee, interpretada pela atriz estadunidense Danielle Brooks (Figura 5), é outro exemplo de personagem negra que ganhou vida própria em relação ao livro.

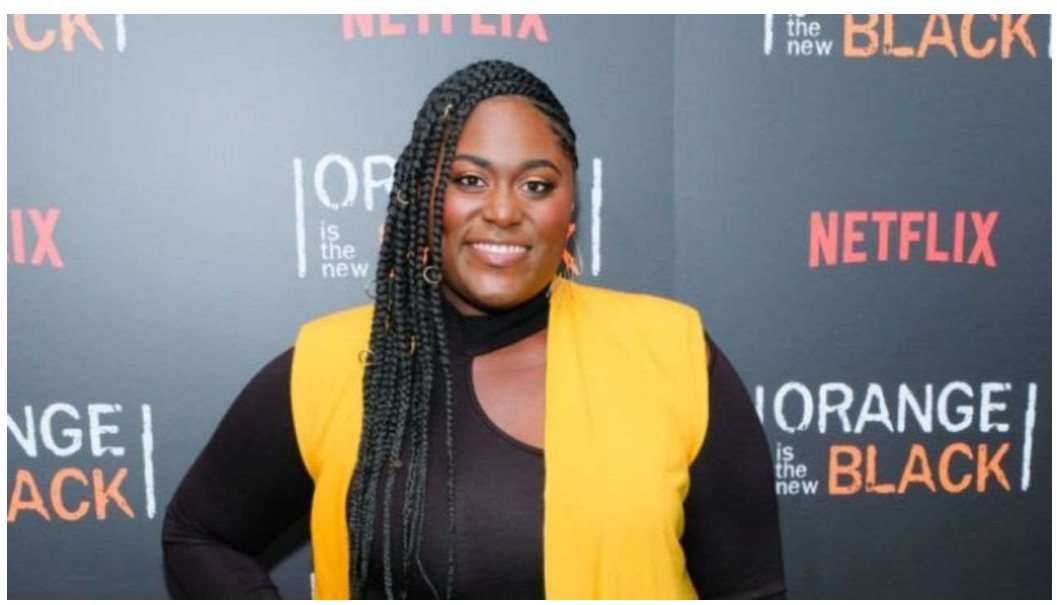

Figura 5 - Danielle Brooks.

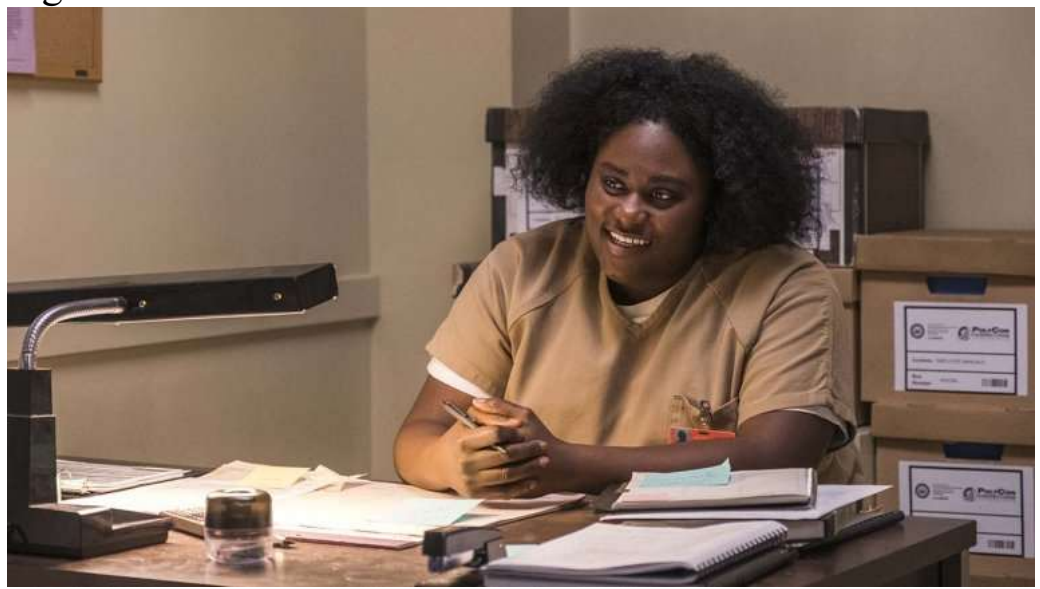

Figura 6 - Danielle Brooks interpretando Tasha.

Tasha é uma das personagens que foi crescendo em protagonismo na série. Passou parte da infância em um orfanato até ser adotada por uma traficante de drogas que a colocou nos "corres" desde muito cedo. Em uma das temporadas ela ganhou liberdade, Revista Caminhos da Educação: diálogos, culturas e diversidades. CAEDU/UFPI 


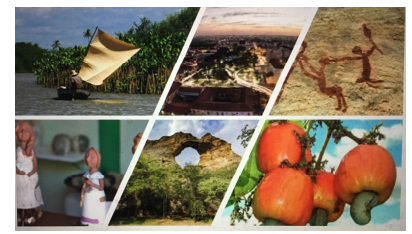

ISBN: 2675-1496 DOI: https://doi.org/10.26694/caedu.v1i2.9831

reincidiu no crime e voltou à prisão por falta de oportunidades e de apoio fora da penitenciária - como acontece com a grande maioria das presas pobres, pretas e pardas: o tráfico as recebe de braços abertos, enquanto a sociedade civil as discrimina ainda mais. O livro, no $13^{\circ}$ capítulo, por exemplo, conta o episódio da simulação para uma entrevista de empregos. Um grupo externo vem ensaiar como aproveitar oportunidades profissionais no momento da entrevista e seleciona três voluntárias para a dramatização. Entre elas está Tasha (também apelidada de Pompom), que veste um tailleur rosa e é desqualificada por seu visual ser julgado "muito fofo". Essa entrevista tem outros desdobramentos na série (na segunda temporada). Apesar da roupa "inadequada", Taystee é a mais destacada na entrevista mostrando situações criativas para solucionar problemas. Esse fato é usado por ela para barganhar uma oportunidade de trabalho privilegiado na prisão: assistente do então diretor Caputo (Figura 6), na quarta temporada, visto que antes ela trabalhava na limpeza. É uma personagem que conquista a confiança e amizade do diretor por suas atitudes inteligentes. No entanto, isso não a salva do pior julgamento que enfrenta na série sob acusação de ter matado um guarda ao final de uma rebelião (quinta temporada). Ou seja, todo seu carisma e inteligência não a salvou de ser considerada suspeita e julgada culpada de um crime - ainda que não o tenha cometido. A série levanta a discussão do medo que comumente pessoas negras têm de ir a júri popular nos EUA - e Tasha decidiu ir -, no entanto, não desfaz a acusação e sua inocência que não é provada. Mesmo assim, ela segue confiante ao descobrir, no dia do julgamento, que existiam tantas pessoas negras organizadas em movimento, lutando para que, como Tasha, outras não passassem por julgamentos racistas.

Outro tema abordado na série é a hipersexualização das negras e latinas e o drama da maternidade. "A criminalização de mulheres negras e latinas inclui imagens persistentes de hipersexualidade que servem para justificar os abusos sexuais cometidos contra elas tanto dentro quanto fora das prisões" (DAVIS, 2018, p. 86). A personagem latina Daya (Dayanara Diaz), interpretada pela atriz dominicana naturalizada estudunidense, Dasha Polanco, protagoniza uma série de abusos sofridos, a começar por um envolvimento sexual consentido com um dos agentes prisionais - no livro o agente é 


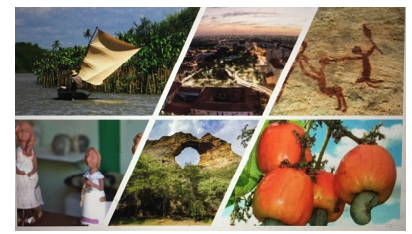

ISBN: 2675-1496 DOI: https://doi.org/10.26694/caedu.v1i2.9831

brevemente mencionado como Sr. Maple, mas na série ganha mais espaço e se chama Bennet. Daya e Bennet vão da atração às vias de fato. Ela engravida e entra numa sequência de abusos que envolvem estupros, agressão física e uma série de situações que, até o final da série, a deixam completamente vulnerável à violência das drogas e da própria família. A feminização da pobreza atinge em cheio as mulheres pretas ou pardas que já enfrentam situações de abandonos fora das prisões: criam filhos sozinhas ou com a ajuda das mães e irmãs. Quando são presas, agravam-se as vulnerabilidades e as famílias sofrem. Laços entre mães e filhos/as são rompidos e o Estado nunca reparará isso. Sem falar na dupla pena que pagam na prisão, onde são esquecidas, traídas e malvistas pelos seus companheiros. É muito difícil recuperar a autoestima de uma mulher que passa pelo cárcere, devido às humilhações pelas quais são submetidas. As mulheres, e ainda mais as negras e indígenas, são vítimas de uma violência patriarcal, como define bell hooks, que para além da violência doméstica, "está ligada ao sexismo e ao pensamento sexista, à dominação masculina" (2018, p. 96).

Duas personagens amadas pela Piper do livro e da série são: a Pop ou Red, apelidos de Galina Reznikov, interpretada pela experiente atriz estadunidense Kate Mulgrew; e a Erica Jones, que no livro é Janet Ioga. Red, ao longo da história, vê seu poder decaindo dentro da prisão, inclusive com perda de memória depois de passar um tempo na solitária. A solitária é uma punição mais frequente na série do que no livro, onde aparece mais como ameaça e medo. Red é uma personagem incrível que mostra o poder de adaptação de uma pessoa, sem perder a dignidade, a honradez e princípios. Ela era severa, talvez a vida a tenha tornado assim, afinal, era uma russa nos EUA. Ela impunha condições e regras na cozinha (setor que comanda no início da série), mas é também sensível, identifica facilmente as características das pessoas e sabe discernir quem tem generosidade como ela. No livro, Erica Ioga parece ter muito mais proximidade com a Piper que na série. De fato, Janet é essa guia espiritual que ajuda a equilibrar os corpos limitados pelo encarceramento com a prática da Yoga, alongamento e meditação. Piper leva a sério o aproveitamento do tempo para manter o corpo são. Além dos ensinamentos de Janet, ela corria diariamente na pista de $800 \mathrm{~m}$ do presídio. No $15^{\circ}$ 


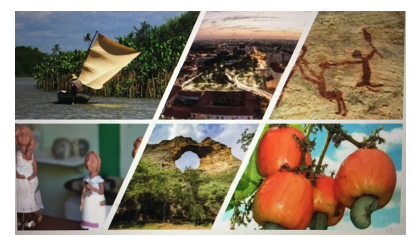

ISBN: 2675-1496 DOI: https://doi.org/10.26694/caedu.v1i2.9831

capítulo do livro, depois de um ano presa, Piper diz que já corria $20 \mathrm{~km}$. Na primeira temporada da série ela disse para o noivo, antes de ser presa, que aproveitaria a prisão para manter o corpo em forma - ainda que a questão não receba grande destaque nas temporadas posteriores.

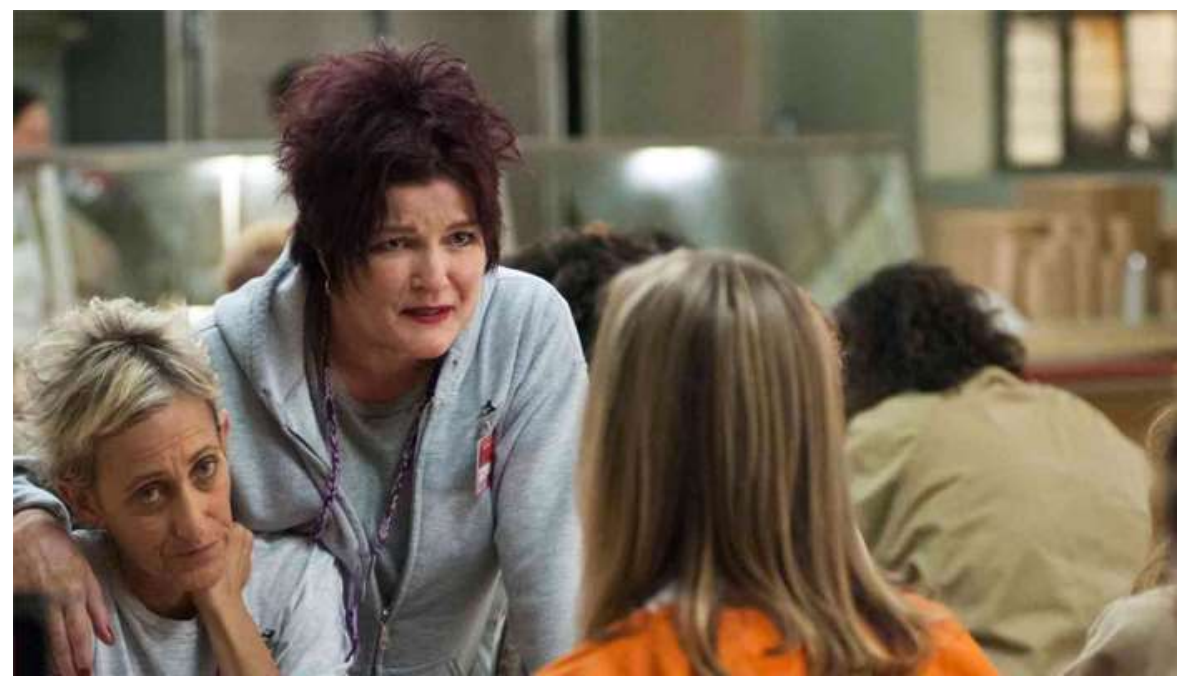

Figura 7 - Red ou Pop (interpretada por Kate Mulgrew) de pé e Erica Jones ou Yoga Jones (interpretada por Constance Schurman).

A Piper do livro em muito se diferencia da Piper da série. É verdade que a autora do livro que originou a série é uma mulher de classe média alta, graduada em nível superior, pertencente ao padrão de beleza branca e se envolveu com o tráfico, inicialmente, para viver uma aventura e não por necessidade real de sobrevivência. Foi nesse período que ela se envolveu com Nora - a Alex da série. As duas personagens têm nomes, características, personalidades e envolvimentos diferentes no livro e na série assim como acontece com outras personagens. A Piper do livro amadurece muito antes de vestir o macacão laranja pela primeira vez no lugar do tubinho preto, afinal se passaram muitos anos enquanto esperava a ordem de prisão. Em suas palavras: "Já tinha lido todos os livros disponíveis na Amazon a respeito de como sobreviver à prisão, mas todos haviam sido escritos para homens" (p. 39).

De fato, são vários os clássicos da literatura sobre pessoas que viveram histórias incríveis no cárcere, mas sempre homens. Quem não lembra do Jean Valjean de $O s$ Revista Caminhos da Educação: diálogos, culturas e diversidades. CAEDU/UFPI 


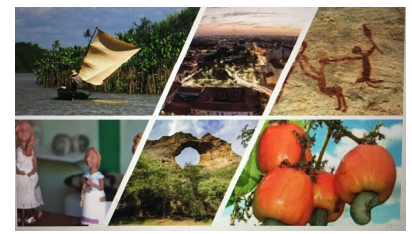

ISBN: 2675-1496 DOI: https://doi.org/10.26694/caedu.v1i2.9831

Miseráveis (Victor Hugo, 1862); ou do Papillon, personagem autobiográfico dos anos 1930, de Henri Charrière, em livro homônimo que foi sucesso na interpretação estadunidense de 1973? São dois exemplos bastante conhecidos de homens presos injustamente e que depois de muitos anos de sofrimento em cárcere se libertam. Mas a lista é longa. Podemos dizer que o protagonismo masculino é que domina o mercado da produção literária e fílmica sobre encarceramento, histórias de resiliência, de esperteza e de sucesso que têm se reproduzido também em algumas séries, como Prison Break, exibida entre 2005 e 2009, e retomada para novas temporadas em 2017.

Todavia, depois do pioneirismo e sucesso de Orange is the new black sobre mulheres encarceradas a partir do lugar de fala de uma delas e ainda, dirigido e produzido por mulheres, estreou uma outra série sobre o mesmo tema: Vis a vis. A série espanhola foi exibida entre 2015 e 2018 e estreou na Netflix brasileira em 2019. Mas, apesar de a protagonista ser mulher, as histórias se desenvolvem dentro de uma normativa heterossexual que parte de um lugar de submissão da mulher - não utiliza a mesma fórmula de Orange.

Piper narra seu drama da experiência do encarceramento, mas ela é consciente do seu privilégio de raça e classe. É uma mulher branca, de classe média alta, quando ainda muito jovem teve relacionamentos homoafetivos e viveu experiências menos convencionais, mas também frequentou universidade e era bem desenvolta. Ela mesma reconhece que apesar de ter sido duro suportar quinze meses dentro de uma penitenciária, poderia ter sido bem pior se só lhe restasse contar com um defensor público e ainda ter o azar de ser um péssimo profissional. Ela diz no livro: "Eu tive um advogado particular fantástico e um terninho elegante para combinar com meu cabelo louro" (p. 143). Essa frase diz de um lugar de fala, de uma prerrogativa privilegiada pela classe, pelo gênero e pela cor da pele, que poderia impressionar e mudar o destino de quem é julgado, dependendo de sua "natureza". Na série, o advogado nem parece tão bom assim, inclusive a abandona depois do julgamento na segunda temporada, mas ela não é representada de maneira menos privilegiada. Outro momento, na mesma temporada, de privilégio de mulher branca, é quando Piper consegue uma licença judicial para acompanhar o funeral 


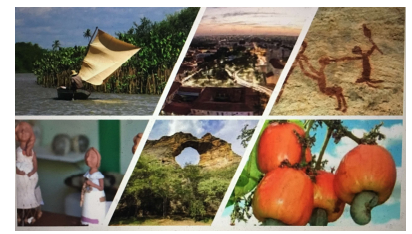

ISBN: 2675-1496 DOI: https://doi.org/10.26694/caedu.v1i2.9831

da sua avó, fato que no livro não se realiza, apesar de ter sido solicitado. Piper é uma pessoa amável e generosa no livro: aprendeu ofícios na prisão e compartilhava seus saberes para que outras pudessem ter pequenos prazeres (como o caso do conserto do ventilador) e seus bens preciosos - livros que recebia de amigos e familiares. Na série, aprendeu a ser egoísta e menos solidária que no livro. Ao contrário dessa sororidade, parece que o que predomina na adaptação é uma relação capitalizada, por meio da qual ninguém faz nada gratuitamente e tudo tem um preço.

Em todo o livro, há muito menos romance entre mulheres do que na série e muito menos sexo. O relacionamento homoafetivo de Piper com Nora ou Alex é a engrenagem que vai levá-la a situação da condenação - tanto no livro quanto na série. Na Europa elas tiveram juntas acesso a toda luxúria, incluindo hotéis, serviço de quarto e acesso às drogas caras, até que uma troca de malas no aeroporto as põe no alvo de uma investigação sobre uma rede de narcotráfico em Londres proveniente da África. A série desenvolve a relação de Alex e Piper dentro do sistema prisional e as várias situações enfrentadas juntas, passando pelo ódio de Piper ao culpar Alex por estar ali até a reconciliação e as várias enrascadas para as quais buscam soluções juntas. No livro, elas só se reencontram por um momento. Nora não compartilhou o mesmo ambiente prisional que Piper, exceto por um breve período em que as duas foram realocadas para uma outra prisão para prestar um depoimento contra o traficante que chefiava a operação de narcotráfico internacional. Todos os outros relacionamentos homoafetivos que surgem ao longo da série não estão presentes ou são explorados no livro. A série foi muito além do livro ao explorar temáticas muito presentes no ambiente prisional feminino.

São várias as personagens da série que desenvolvem relacionamentos homoafetivos, além de Piper e Alex. Algumas assumem papéis dominantes e de conquistadoras, como a Boo (maravilhosamente interpretado por Lea Delaria) e a Nicky (emocionalmente interpretado por Natasha Lyonne); outras se deixam conquistar como a Lorna Morello (interpretada por Yael Stone) que cede às investidas de Nicky apesar de sonhar e fazer de todo o possível para se casar e ser mãe. Uma história de amor entre duas mulheres e personagens graciosas da série é a que se passa entre Soso (interpretada por 


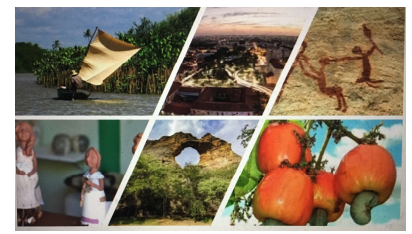

ISBN: 2675-1496 DOI: https://doi.org/10.26694/caedu.v1i2.9831

Fimiko Glenn) e Poussey (interpretada por Samira Willey) - todavia, o relacionamento tem um fim trágico com a morte de Poussey, o que provoca uma reviravolta na série: uma rebelião de largas proporções.

Ainda sobre relacionamentos homoafetivos, todas enfrentam a heteronormatividade compulsória ou apresentam conflitos morais que as reprimiram em algum momento ou situação. Em meio a elas existe uma personagem cujo sexo é confrontado com violência: a Sophie (Vanessa Robinson, no livro), interpretada por Laverne Cox, uma mulher trans (no livro, na série e na vida real também ativista) que vive o drama de manter um corpo em transformação num lugar que por vezes não fornecia os hormônios que lhe eram necessários, fazendo com que exalasse suores masculinos e tivesse sua voz engrossada. Na série, Sophie protagoniza outros dramas da violência que humilha pessoas trans, intensificados em situação prisional. Ela, no entanto, não se relaciona sexualmente com ninguém e recebe visitas da ex-esposa e filho. No Brasil, as mulheres trans não têm a possibilidade de ficarem presas com outras mulheres. Na maior parte das unidades prisionais dividem celas com homens; com sorte, em algumas ficam em alas LGBT - de uma maneira ou outra são negligenciadas e sujeitas a uma série de violências.

A exploração capitalista é particularmente evidenciada na terceira temporada, quando parte das presas passa a trabalhar em uma fábrica de calcinhas coordenada pela administração do presídio, dali surgiu um negócio paralelo comandado por Piper. Algumas peças eram desviadas e comercializadas, depois de usadas pelas presas parceiras, no mercado clandestino. São tramas que confrontam a exploração do capital que impõe com frequência longas jornadas de trabalho às mulheres presas, com baixos custos, altos rendimentos e o risco de envolvimento com a ilegalidade permanece uma tônica na rotina da prisão. Apesar de toda interdição nos ambientes prisionais, o comércio ilícito está presente e há toda uma rede de favorecimentos. Angela Davis (2018, p. 91) explica o termo "complexo industrial-prisional" que se aplica bem a esse ponto desenvolvido na série. Diz ela: “A exploração da mão de obra prisional por corporações privadas é apenas um dos aspectos de uma série de relações que ligam corporações, Revista Caminhos da Educação: diálogos, culturas e diversidades. CAEDU/UFPI 


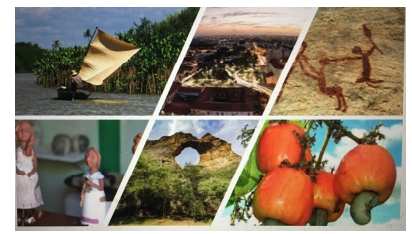

ISBN: 2675-1496 DOI: https://doi.org/10.26694/caedu.v1i2.9831

governo, comunidades correcionais e mídia". Vale ressaltar que se trata de exploração racializada e racista, pois afeta diretamente as populações negras em maior número, seguido por latinas (imigrantes ilegais geralmente provenientes dos países vizinhos da América do Sul), nativas americanas e asiático-americanas - no caso dos EUA. Quanto maiores as penas, maiores os lucros e a promoção dos pensamentos e práticas favoráveis à expansão do encarceramento em massa, por meio da privatização dos presídios. Vale lembrar que, depois dos EUA ocupar o primeiro lugar, o Brasil está em terceiro entre os países que mais encarceram mulheres.

O racismo que se liga diretamente à condenação racial é histórico, uma continuação do sistema escravagista baseado na punição. Desde o século XIX, nos EUA e no Brasil, quando se aboliu a escravidão, permaneceu um sistema de punição das pessoas negras que nunca foram tratadas como iguais, por isso elas sempre são julgadas suspeitas por delitos e crimes. Em todo o mundo a grande maioria da população carcerária pertence a minorias étnicas e raciais. Angela Davis defende uma perspectiva de redenção: "se conseguirmos argumentar com sucesso que as prisões são instituições racistas, isso pode nos levar a encarar com seriedade a perspectiva de declará-las obsoletas" (2018, p. 27). A falta de perspectiva de reintegração social é gritante. No Brasil e mesmo na série vemos vários fatores se apresentarem: a baixa escolaridade das pessoas mais pobres e as distâncias culturais entre imigrantes latinos, afro-americanos e asiáticos perpassam vários episódios.

Também o abandono é dramático. Nos presídios brasileiros temos a problemática das mulheres que enquanto reclusas são abandonadas por familiares, amigos, filhos e esposos, o que faz com que se vejam reféns do sistema e do crime, não tendo a quem recorrer ou a quem pedir ajuda, ficam expostas a todo tipo de situação. Algumas fazem a revenda de entorpecentes na comunidade carcerária, por exemplo. Muitas mulheres entram nos presídios com penalidades mínimas, mas com o passar do tempo acabam aumentando seu tempo de detenção, por assumirem drogas de traficantes que dominam o sistema carcerário e servirem como funcionárias do tráfico. Entre outros delitos enquanto presas, recebem ajuda jurídica por parte dos criminosos ou ajuda financeira para compra 


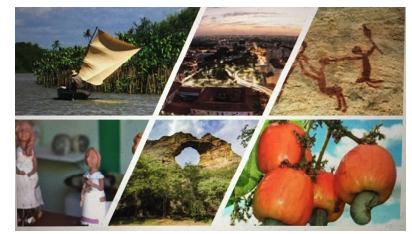

ISBN: 2675-1496 DOI: https://doi.org/10.26694/caedu.v1i2.9831

dos materiais de higiene pessoal e mantimento alimentício. Essas mulheres que se encontram em situação de vulnerabilidade se veem cada vez mais à mercê da criminalidade, criando redes de dependência sem fim. Além de tornar a pessoa escrava por meio do endividamento material e jurídico, usa-se dessa mesma estratégia para o endividamento por meio de fornecimento de drogas para consumo próprio; assim, a pessoa se torna mais uma vez escrava, não apenas do vício, mas, por consequência, do crime. Com certeza o uso do vício para controlar essas pessoas é a forma mais baixa e desumana de todas, uma vez que o crime usufrui da fraqueza do indivíduo para obter lucros e vantagens, não se importando com as consequências causadas na vida dessas mulheres nem com as família e filhos que em geral possuem. Essas dívidas contraídas como suposta ajuda dentro das prisões não se finda com a saída do sistema, porque, caso não sejam quitadas ainda enquanto presas, ao retornarem às ruas essas mulheres são obrigadas, quer queiram ou não, a cometer novos delitos com o fim de quitar tais compromissos. Caso se recusem, correm o risco de pagar com a própria vida ou com a vida de algum parente. $\mathrm{O}$ drama do tráfico de drogas está presente no ambiente carcerário feminino, visto que cerca de $60 \%$ da população carcerária feminina foi seduzida (ou induzida) ao crime, uma vez que a beleza e a suposta fragilidade da mulher são consideradas facilitadoras para a venda e o transporte de produtos ilícitos. Logo, a reincidência no crime é fatal e comum, uma vez que o que resta para essas mulheres é a retomada de crimes para o sentido próprio e familiar. A grande maioria delas são mães e necessitam desse dinheiro para sua manutenção e de seus filhos, até mesmo para as despesas mais básicas.

Como tudo no sistema prisional é escasso e difícil de se conseguir, é normal que quem tenha um poder aquisitivo maior possa se favorecer sobre àqueles de menor poder, assim passando a possuir serviçais para tarefas diárias, como faxinas, até mesmo conseguindo pagar para que outros assumam a culpa por atos criminosos de terceiros, dentro ou fora dos presídios. Esse aproveitamento não vem só por parte do crime, mas o próprio Estado se utiliza da situação de vulnerabilidade dessas pessoas para se favorecer economicamente, a exemplo das ofertas de trabalho sem as mínimas condições de Revista Caminhos da Educação: diálogos, culturas e diversidades. CAEDU/UFPI 


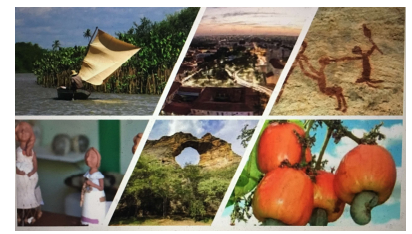

ISBN: 2675-1496 DOI: https://doi.org/10.26694/caedu.v1i2.9831

dignidade e salubridade. As mulheres presas normalmente são exploradas como serviçais em tarefas subalternas de limpeza e cozinha, recebendo salários exíguos e reproduzindo os papéis domésticos frequentemente atribuídos a elas. Essa máquina de exploração do capital beneficia o Estado, suas repartições e bancos.

Dráuzio Varella (2017, p. 78), depois de sua experiência voluntária de onze anos como médico na Penitenciária Feminina da Capital de São Paulo, reforça que o trabalho constitui uma das principais aspirações da massa carcerária, "menos por amor a ele do que por razões fáceis de compreender: além de combater a ociosidade das horas, dos anos e meses que se arrastam - um dos flagelos mais angustiantes da vida carcerária -, a cada três dias trabalhados descontam um da pena a cumprir". No entanto, nem todas são consideradas aptas à remição de pena por trabalho e ainda são poucas as empresas que aceitam empregar detentas ou detentos, cabendo esse encargo, em geral, aos órgãos públicos. Da remuneração baixa apenas uma parte fica para as despesas pessoais, o restante indo para uma poupança que assegure algum recurso para quando for posta em liberdade, também uma parte pode ir para algum familiar indicado pela presa ou ainda para algum ressarcimento ao Estado, se determinado judicialmente. O trabalho, ainda que sob essas condições, é mais atraente para a remição de pena que os estudos.

Estudar pode tornar menor a pena no Brasil, pois a cada doze horas frequentadas na escola diminui um dia de pena. Ainda há a possibilidade de remição pela leitura de obras literárias: a cada obra lida e resenhada, no prazo de 21 a 30 dias, dá a possibilidade de remição de quatro dias da pena. A Lei de Execução Penal garante o acesso à educação na forma da instrução escolar e formação profissional às pessoas privadas de liberdade, mas segundo relatório mais recente do Infopen Mulheres, "apenas 25\% da população prisional feminina está envolvida em algum tipo de atividade educacional, entre aquelas de ensino escolar e atividades complementares" (SANTOS, 2017, p. 67). A reeducação deveria ser o intuito primeiro daqueles que designam essas mulheres como reeducandas. Reeducar (reabilitar, reparar, regenerar - sinônimos de dicionário), no entanto, não é o foco prioritário que acompanha as políticas de encarceramento. 


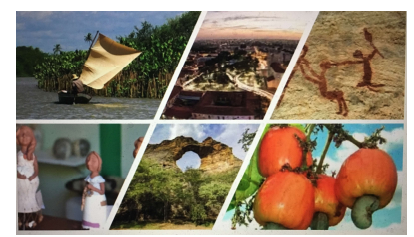

ISBN: 2675-1496 DOI: https://doi.org/10.26694/caedu.v1i2.9831

A série desenvolve a importância da leitura e a diferença que os livros fazem na vida de várias personagens. Um dos episódios marcantes é o do funeral dos livros, na terceira temporada, quando depois de a biblioteca passar por uma infestação de pulgas a administração ordena a incineração dos livros. Na cena, Taytee e Poussey homenageiam vários autores clássicos enquanto despejam as cinzas próximo às árvores. Outra situação que mostra da importância dos estudos e protagonizada pelo drama de Dogget, a Pennsatucky. Na última temporada, depois que ela resolve fazer as provas do supletivo, com ajuda das colegas de prisão, lutando contra a dislexia que a expulsou da escola, ela não suporta esperar o resultado, com medo da derrota mais uma vez, seu final é trágico e ela não chega a receber a notícia da aprovação.

A marca que a passagem pelo sistema prisional deixa é indelével e não se finda com a soltura. Após o pagamento da dívida com a justiça, a mulher que viveu dentro da comunidade carcerária fica marcada o resto da vida e com esse histórico fica difícil a retomada ao mercado de trabalho ou qualquer atividade desenvolvida na sociedade. Além da falta de oportunidade para essas mulheres, também falta capacitação para as mesmas, porque elas saem do sistema como entraram, senão pior, visto que raríssimas são as oportunidades de profissionalização. Como diz Juliana Borges (2018, p. 16): "Ser encarcerado significa a negação de uma série de direitos e uma situação de aprofundamento de vulnerabilidades".

O descaso dos órgãos responsáveis pelo sistema prisional é ultrajante e a série traz à tona essa problemática, revelando a falta de compromisso estatal em relação às detentas. Na série e no livro podemos ver os responsáveis pela unidade prisional fazendo pouco caso dos reparos necessários no prédio e da situação das detentas. O dinheiro que deveria ser investido na unidade era destinado com frequência à objetivos distintos, ou mesmo interesses pessoais diversos, relacionados à promoção profissional e aspirações de poder. Quem conhece o sistema de perto sabe das mazelas e da precariedade que é: um ambiente hostil e insalubre.

Essas infraestruturas além de serem mal planejadas - em geral não são adaptadas às necessidades particulares de mulheres, por vezes são prédios obsoletos que antes eram 


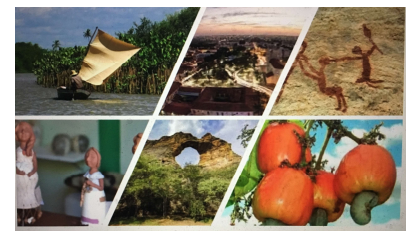

ISBN: 2675-1496 DOI: https://doi.org/10.26694/caedu.v1i2.9831

ocupados por homens - o que aumenta o problema de manutenção. O racionamento de água é comum em várias unidades prisionais e o entupimento dos esgotos também é fato frequente: durante os banhos, em certos casos, a água do esgoto retorna dos canos e os pés ficam expostos à água contaminada por fezes e urina, além do horrível mal cheiro, fatores que tornam o ambiente desumano. Na série, logo no início, a Piper recebe de presente um chinelo de borracha para banho, para proteger os pés dessas possíveis contaminações nos banheiros. São situações corriqueiras e diárias, aqui e lá nos Estados Unidos. Na série esse tipo de situação é contornado, mas imaginemos como é a realidade dos sistemas prisionais de países menos favorecidos economicamente.

Então, conclui-se que a retirada dessas mulheres da sociedade não resolve o problema da criminalidade. É necessário a capacitação delas para que seja possível sua reinserção à sociedade. Precisamos que o Estado se dê conta que a exploração trabalhista das mulheres nos presídios e sua dupla condenação não é um caminho digno a ser seguido. Mediante todas essas realidades expostas podemos afirmar que enquanto o sistema prisional for visto apenas como local de contenção, estaremos longe de solucionar esse problema que causa proporções catastróficas à sociedade.

Piper sai da prisão no fim da sexta temporada da série e no último capítulo do livro. A sétima e última temporada retrata o processo de readaptação dela à sociedade. Mas o que de novo transparece é o privilégio branco e de classe, enquanto várias outras mulheres acabam tendo fins trágicos. A série, independente de conhecermos mais ou menos das realidades do encarceramento, diz dos sentidos de humanidade e do quanto as mulheres são estigmatizadas e atravessadas pelos preconceitos de classe e raça. A prisão é também uma condição que acompanha a existência feminina, de onde é tão difícil se libertar das culpas, das penas e cobranças que aprisionam e oprimem as mulheres, sobretudo as negras e indígenas, cujos corpos foram tão colonizados quanto os países sobre os quais tratamos.

\section{Referências}




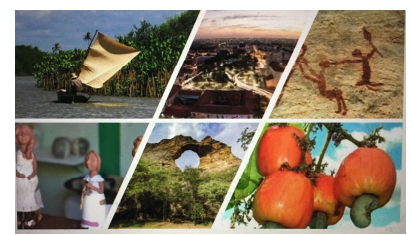

ISBN: 2675-1496 DOI: https://doi.org/10.26694/caedu.v1i2.9831

BORGES, Juliana. O que é encarceramento em massa? Belo Horizonte: Letramento; Justificando, 2018.

DAVIS, Angela. A liberdade é uma luta constante. São Paulo: Boitempo, 2018. Estarão as prisões obsoletas? 2. ed. Rio de Janeiro: Difel, 2018.

HOOKS, bell. O feminismo é para todo mundo: políticas arrebatadoras. Rio de Janeiro: Rosa dos Ventos, 2018.

KERMAN, Piper. Orange is the new black. Rio de Janeiro: Intrínseca, 2014.

SANTOS, Thandara (org.). Levantamento Nacional de Informações Penitenciárias. INFOPEN Mulheres. 2. ed. Ministério da Justiça e Segurança Pública; Departamento Penitenciário Nacional, 2017.

VARELLA, Drauzio. Prisioneiras. São Paulo: Companhia das Letras, 2017.

RECEBIDO: $22 / 05 / 2019$

APROVADO:03/07/ 2019 